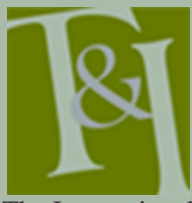

The International Journal for Translation \& Interpreting Research trans-int.org

\title{
Translation (in/of/as) history: toward a model for historicising translation in Hispanic Filipino literature
}

\author{
Marlon James Sales \\ University of Michigan, Ann Arbor/ KU Leuven \\ mjsales@umich.edu
}

DOI: 10.12807/ti.111202.2019.a04

\begin{abstract}
The task of researching the history of translation within the framework of a national literature overlaps with the task of interrogating the uses of translation in imagining a nation's history. Although translation may be represented in this context as a neutral and unproblematic search for equivalence between languages, translational acts have been employed, either wittingly or unwittingly, to privilege $a$ past and inscribe it into the accepted national narrative. Such is the role of translation in the history of Hispanic Filipino literature. In this article I argue that the endeavour of writing a translation history using Hispanic Filipino texts is called upon to examine translation in history, of history and as history, that is, how translation operates as a material, method and mode of commemoration. Translation is considered here as a fundamental component in the production and mediation of a text. It fulfils a gatekeeping function through which historical information is repatriated into the national consciousness.
\end{abstract}

Keywords: history of translation, Spanish Philippines, literatura hispanofilipina, Jose Rizal, Pedro Paterno, Isabelo de los Reyes

\section{Introduction}

The Philippines is an underrepresented area in the study of Hispanism. While there is an awareness about the interconnections between this Southeast Asian archipelago and those regions we readily identify as Hispanic, attempts to investigate Filipino Hispanism are sparse and are often tinged with colonial nostalgia. Studies written in Spain have generally failed to engage with the particularities of the Filipino experience (Fradera, 2001, p. 99), while those written by Filipinos commonly resort to an indigenist critique on the entanglements of cultural production with class politics (Donoso Jiménez, 2014, pp. 9-10). There is also a problem in categorising the Philippines under the often imporous divisions of area studies, given the perception that the country is not quite Hispanic (Zialcita, 2009, p. 164). The Philippines is thus effaced from Hispanic studies, and along with it go approaches for studying Asia using Spanish-language sources (Lifshey, 2016, pp. 7-8).

Similar tensions pervade Hispanic Filipino literature, defined provisionally as Filipino literature written in Spanish (Álvarez Tardío, 2014, p. 41). Among the many characteristics ascribed to it, its ontological peculiarity proves difficult to miss. Álvarez Tardío (2012), Lifshey (2012) and Ofilada Mina (2014), among others, have underscored the fraught nature of a literature written in a language that has remained inaccessible throughout history to an intended national readership. Spanish was never a Philippine lingua franca despite its status as an official language from 1565 to as late as the second half of the twentieth century. By 1870, or about three decades before the end of the Spanish 
rule, Spanish speakers in the country amounted to about three percent of its inhabitants (Hau \& Tinio, 2003, p. 338). Census figures from 2013 show that there are only about three thousand speakers of the language in a population of about a hundred million (Fernández Vítores, 2017, p. 7). This meagre demographic position of Spanish is incommensurate to its importance in the country's heritage. Spanish accounts for about a fifth of words in Tagalog ${ }^{1}$ and Cebuano, the two most spoken Philippine languages (Quilis Sanz, Quilis, \& Casado Fresnillo, 1997, p. 7). There are also numerous foundational texts, legal jurisprudence, historical documents, and literary masterpieces in Spanish that are still consulted today, apart from other tangible and intangible cultural iterations.

Since Hispanic Filipino texts are mostly accessed by the national readership in their translations into English, Filipino or, less frequently, any of the country's other indigenous languages, one might expect that translation is a foremost concern in Hispanic Filipino literature. This, however, is not the case. Notwithstanding the efforts by postcolonial scholars like Rafael (2005) and Guillermo (2009) to bring translation to the fore, research within Hispanic Filipino literature itself is reluctant to fully engage with translation (cf. Gallo, 2012). Scholarship in the field is likewise saddled with the alleged inadequacy of authors who "could not read Spanish and who depended on still earlier commentary by people also apparently unfamiliar with the original texts" (Lifshey, 2016, p. 9).

Such allusions to the discontents of translation are a reflection of a wider range of issues in world literature and world history that translation studies hopes to address. Each of these disciplines prioritises a different aspect of translation, with scholars in translation studies focussing more on the complexities of translation as a cultural phenomenon, and those from other disciplines, on its uses as a tool for research (Paloposki, 2013, p. 221). This prevents the ideas we have devised in translation studies from guiding transdisciplinary conversations more effectively. It is still assumed in some quarters that world literature and world history can exist independently of each other (Robbins, 2018, pp. 194-195), an illusory autonomy replicated between history and translation (Rundle \& Rafael, 2016, pp. 29-30). In the Philippines specifically, much of what is researched in translation history converges around the traditional notions of translation as an intermediary transfer between two monolingual texts, or as an impoverished by-product of this transfer. The emphasis on Spanish as the language of Hispanic Filipino literature and the implied distinction between literature and translated literature reinforce these notions. What these notions tend to do, however, is ignore those texts, both originary and derivative, where translation is a fundamental element of composition, and where the fact of being translated is in itself a key message to be conveyed.

It is in this context that I am proposing to unpack translation history as translation (in/of/as) history. Delisle (2008, p. 83) stresses that the historiography of translation should not be a simple listing of texts, anecdotes, biographies, and references to translation in the historical records. Rather, it must make meaningful connections over long periods of time between the translational acts in question, and the social, cultural, political, and/or economic conditions in which they were ensconced. But even this already capacious definition of translation historiography may still be limiting if we review how translation was used in the Philippines for writing history. It is worth recalling the work of Cano (2008), who detected grave mistranslations in the monumental 55-volume series called The Philippine Islands, 1493-1803, a staple resource for researching Philippine colonial history. The series was published by Emma Blair and James Robertson at the beginning of the US occupation. Their translations into English of primary Spanish-language materials on the Philippines were said to uphold the 'black legend' that American bureaucrats 
deployed to demonize the Spanish conquest and, by contrast, extol the US imperial project. We see this trope repeated in other translations produced during the period. Translation was also one of the concerns raised by William Henry Scott (1984) in his discovery of fabricated Spanish-language documents that supposedly established the existence of a pre-Hispanic legal codex called Kalantiyaw. The unpreparedness of researchers back in the day in testing the veracity of these documents - which were taken as factual for a long time stemmed from an uncritical dependence on the available translations and the scholarship built on them (pp. 132-134). Of late, even Benedict Anderson himself had to rewrite parts of his celebrated book Imagined communities after realising that the translations of the Hispanic Filipino texts he cited were deficient (2006, pp. xii-xiii, 26-27).

Cases like these are indicative of the enmeshment of translation in Filipino history and literature. Much of our recorded history from the early years of colonial rule was pieced together using the writings of the Spaniards themselves. When indigenous interlocutors became more visible in the eighteenth and nineteenth centuries, many of them had to write in Spanish in order to participate in the conversation. This did not happen without controversy. Consider the example of the Sucesos de las islas Filipinas [Events from the Philippine Islands] (Sucesos hereafter), ${ }^{2}$ a chronicle written by Antonio de Morga and published in Mexico in 1609. ${ }^{3}$ The Filipino intellectual and national hero José Rizal republished the Sucesos with his own annotations in 1890 in a bid to offer his countrymen a more lucid assessment of colonialism (p. V). At that time, the version of the Sucesos that was widely circulating was Lord Stanley of Alderley's 1868 English translation, whose biggest merit, according to the Austrian academic Ferdinand Blumentritt in his prologue to Rizal's edition (p. VIII), was to make scholars realise that there was a need to reprint the work in its original language. Nevertheless, Rizal's edition did not get distributed as widely as expected. It was banned in the Philippines on grounds that its annotator was a subversive (Morga \& Retana, 1909, p. 177).

Seen from this vantage point, Delisle's idea for translation historiography becomes somewhat incomplete because it does not fully account for situations where historical writing and translating have become inextricably linked. Translation is not only a subject to be historicized; it can also be a constitutive procedure of historicization and an interpretative disposition for engaging with a historicized past. This is an ethical and political concern in sites where historical remembrance is unavoidably a function of translation (Vidal Claramonte, 2018, p. 6). In such sites, history emerges from an assemblage of literatures not written in a single language but have been cohered into a single narrative of selected past events (Cheung, 2012; Foz, 2006).

The analytical model I am proposing here breaks down translation history and historiography into a study of the materials, methods and modes of commemoration. My model draws partly on D'hulst's work on the objects of translation history (2010) but with a more vigorous emphasis on translation as history's metalanguage. I contend that translation history should be capable of unsettling the idealised concepts of 'translation' and 'history,' of 'translator' and 'historian,' and complicate the relationship between them. In Burke's words (2007):

[i]f the past is a foreign country, it follows that even the most monoglot of historians is a translator. Historians mediate between the past and the present and face the same dilemmas as other translators, serving two masters and attempting to reconcile fidelity to the original with intelligibility to their readers. (p. 7)

Translation (in/of/as) history also fulfils translation history's primary objective of a rescate [rescue] (Bastin, 2010, p. 26) by recovering an untapped cultural and ideological patrimony. Translation repatriates a text exiled in the terrain of the foreign back into the consciousness of the nation. The relevance 
of a text to a nation that no longer speaks its language lies in the awareness that this text endures as a fact of culture because it can lend itself to translation. The nation becomes both the source and the target of translation, and the nation's history, a concatenation of translated pasts.

This article explores translation (in/of/as) history in three thematic cases in the longue durée of Hispanic Filipino letters. This period extends from the second half of the sixteenth century, when the islands were placed under Spanish rule, to the first half of the twentieth century, the so-called 'Golden Age' of Hispanic Filipino literature, which happened when the Philippines became a US colony. For my purposes, the definition of literature I am adopting is the one used by Ofilada Mina (2014, p. 56) and Peralta-Imson (1997, p. 2), which encompasses even those texts created not just for art's sake. These thematic cases, while still admittedly insufficient in formulating methodological generalisations about translation history, illustrate the overlays between literature and history in the Philippines. They are likewise useful in interrogating the relevance of Filipino literature in Spanish in the national consciousness.

\section{Translation in history}

The Philippines has always been a multilingual space. In addition to about a hundred indigenous languages spoken throughout the archipelago, records show that foreign languages were also used to deal with traders from neighbouring places in Asia long before the arrival of colonial settlers. The colonial projects of Spain and the US brought in more languages into this space. The translational activities in the Spanish Philippines involved agents, products and areas beyond the borderlines of the incipient nation-state. It was not infrequent, for example, to read about Philippine-based missionaries who were studying, writing or translating Chinese and Japanese texts, given the Philippines' position in the Spanish colonial imaginary as a springboard for the conversion of East Asia into Christianity.

The translationality of this multilingual space was instantiated in the materiality of its literature. The 1593 Doctrina christiana ['Christian doctrine'], one of the first books published in the Philippines, was a collection of Catholic prayers in Spanish and Tagalog, the latter rendered in both the indigenous script and its Romanised form. Literary translations published by Spanish priests were derived from devotional literature, such as the hagiography of Barlaam and Josaphat, translated into Spanish in 1692 by Fr Baltasar de la Cruz (Medina, 1896, p. 75), and into Tagalog in 1708 by Fr Antonio de Borja (Pardo de Tavera, 1903, p. 70). Translations were also produced by local priests such as Fr Gaspar Aquino de Belén, who translated Fr Tomás de Villacastín's prayers for the dead into Tagalog. To this translation was appended Aquino de Belén's most notable work, the pasyon, a long epic poem made up of five-line verses recounting Christ's life, death and resurrection.

Translations were similarly found in the writings of later secular Filipino authors like Manuel Bernabé, who for his Spanish-language anthology Cantos del trópico [Songs of the tropics] (1929) translated poetry fragments by Francisco Balagtas from Tagalog, and by Omar Khayyam and Thomas Linley from English. It was his translation of Khayyam's Rubaiyat, based on Edward Fitzegerald's translation and published previously in the newspaper $L a$ Vanguardia, which won Bernabé the 1924 Premio Zóbel, the most prestigious literary prize in Spanish in the Philippines (Brillantes, 2006, p. 63). As Hispanic Filipino literature "was virtually married to journalism" from the 1860s onwards (Peralta-Imson, 1997, p. 2), translations also appeared in newspapers. The Manila Bulletin, originally a Swiss-owned shipping journal, published 
translations from English to Spanish, while El Ideal, popular among Filipino nationalists, published from Spanish to English (Veyra, 1961, p. 92).

There were also originary texts composed in translation. The first known specimen of Hispanic Filipino poetry was Salamat nang ualang hanggan [Eternal thanks] by the indigenous bilingual poet Fernando Bagongbanta. It appeared in the Memorial de la vida cristiana en lengua tagala [Memorial of the Christian life in the Tagalog language] by the Spanish philologist Fr Francisco Blancas de San José. The poem comprised eleven verses of alternating lines in Tagalog and Spanish in praise of books as a material for evangelisation:

O sulat na lubhang mahal/ ó libro preciosa pieza,/ icao ang pinagpapalamnan/ tu en ti contienes, y encierras:/ nang dilang magandang aral/ cualquiera doctrina buena/ nacatataos sa loob/ que dentro del alma penetra. (Blancas de San José, 1832 [1605], n.p.)

[O book, precious piece, you contain good doctrine that penetrates the soul!]

Similar poems were recorded in the earliest pedagogical grammar of Spanish for Tagalog speakers, the Librong pagaaralan nang mga Tagalog nang uicang Castila [Book with which the Tagalogs should study the Castilian language] by the Filipino Chinese printer and author Tomás Pinpin. Many of the poems in this grammar were mnemonic devices for memorising Spanish vocabulary. The more well-known poem, however, exhorted indigenous readers to study Spanish so that they would no longer be "brutos salva[j]es" [brute savages] (Pinpin, 2011 [1610], p. 5).

A more radical take on translational poetry was Jesús Balmori's Miusic to Mister Rait [Music to Mister Right], included in his anthology El libro de mis vidas manileñas [The book of my Manila lives]. Published during the US occupation, the poem satirised an evolving linguistic landscape that saw Filipinos adopting English increasingly as a medium of communication:

¡Di finis of di pleys,/ Mast bi uan big estrait,/ For naw Guevara seys/ Yu ar Rait, bat not ol rait!// E buk was sent tu yu,/ En not e litel toy,/ ¡Way dint yu rid da buk?.../ ¡Oh, boy!, ¡oh, boy! ¡oh boy!// ¡Bi esport! Jiar di vois/ Dat yu bifor estud.../ ¡Yu ar meiking so mach nois,/ En dats not eni gud! (1928, p. 7)

[The finish of the place/ must be one big straight,/ for now Guevara says,/ "You are right, but not alright!"// A book was sent to you,/ and not a little toy./ Why didn't you read the book?! Oh boy, oh boy, oh boy!/ Be a sport! Hear the voice/ that before you stood./ You are making so much noise/ and that's not any good!]

In an anthology written almost entirely in Spanish, this poem stood out for its mocking use of English, approximating orthographically how the language would have been pronounced by Spanish-speaking Filipinos. English vowels were replaced by a more simplified system (e.g., /a/ instead of $/ N /$ for the word 'much'), alternative graphemes were used to represent English consonants (e.g., the letter ' $\mathrm{j}$ ' for the word 'hear,' substituting the English / $\mathrm{h} /$ with the Castilian $/ \mathrm{x} /$ ), and the inverted exclamation mark was calqued. Unlike Bagongbanta's and Pinpin's poems, where the component languages remained distinguishable from each other, Balmori's poem invented a hybrid translatese that was neither English nor Spanish. It was through this translatese that the Filipinos' incapability to fully sound American was commemorated in verse.

Examining the materiality of translation in this manner shows that although Spanish was the language in which Hispanic Filipino literature was primarily written, it was set against an intricate backdrop of interdependent multilingual realities both internal and external to the written texts. Translation was a strategy for containing these realities. It memorialized shifts in how Spanish was perceived over time. A recurring theme in the writings of Hispanic Filipino authors was the dissatisfaction over the imposition of English and the upsurge of American influence in the country (Peña, 2001). Spanish, once the language 
of colonial settlers, was stripped of its religious and colonial connotations, and was weaponised against new colonialist ambitions articulated in an equally foreign tongue. We see this reiterated in other translational poems in Balmori's anthology like No, no es lo mismo (pp. 31-32) [No, it's not the same] and La letra con sangre entra (p. 64) [lit. 'the letter enters with blood'].

Yet the contradiction of Spanish was that while it was still claimed as a language of the Philippines, it was more common to translate from it than into it. It was through translation that Spanish-language texts by Filipino authors were accommodated into the national literary mise-en-page, thus creating a sensation of detachment from what was deemed to be innately Filipino. Some masterpieces of Filipino nationalist literature were translated from Spanish during the first half of the twentieth century. These include José Rizal's Filipinas dentro de cien años and La indolencia de los filipinos, translated by Charles Derbyshire as The Philippines a century hence and The indolence of the Filipinos, respectively (Craig, 1927, pp. 222-309); Apolinario Mabini's The Philippine Revolution, a self-translation from Spanish published posthumously by the National Library of the Philippines in 1935; and the Philippine national anthem, written in 1899 by José Palma under the title Filipinas, then translated into Tagalog for the first time by Ildefonso Santos and Julián Cruz Balmaceda in 1940 (Almario, 2009, p. 24).

\section{Translation of history}

Some works in Hispanic Filipino literature were expressly written to translate local history for an international readership. Pedro Paterno's El cristianismo en la antigua civilización tagálog [Christianity in the ancient Tagalog civilisation] (1892; Cristianismo hereafter) was among them. It was published to refute the claim made in the journal La España Moderna by Ramón Martínez Virgil, bishop of Oviedo, that there was hardly anything written by Filipinos on Philippine prehistory. Paterno's interest in the matter was understandable. Despite the honour of being the first indigenous Filipino to write a novel (Ninay, published in Madrid in 1885), he also had the dubious reputation of writing $L a$ antigua civilización tagálog [Ancient Tagalog civilisation] in 1887, described by one contemporary as "una obra de pura fantasía llena de extrañas e increíbles afirmaciones" (Pardo de Tavera, 1903, p. 301) [a work of pure fantasy teeming with strange and unbelievable statements].

Cristianismo was meant to demonstrate not only Paterno's knowledge of history, but also, as he himself stated, his ability to translate between foreign and local manifestations of religious belief (p. VI). But his reliance on translation resulted in a co-opted remembrance of a purported precolonial Christian past, which Paterno constructed based on fanciful readings of religious sources and rambling philological interpretations. For example, he referenced the teachings about Bathala, the supreme precolonial deity, by an obscure Tagalog prophet he called Pithó (pp. XXXVI-XXXVII). For Paterno, Bathala's resemblance to the Christian God was so striking that the logical conclusion what that the ancient Tagalogs practised a pre-Hispanic form of Christianity. This was just one of the many sweeping statements he made to reconcile two different belief systems. At one point, he even claimed that the Tagalogs' gayuma [love potion] was essentially comparable to the consecrated wine in Catholic liturgy (pp. XIII-XIV). Paterno's excessive use of italics to insulate his translations visually from the rest of his discussion made the text, whimsical as it already was, look even more bizarre.

Notwithstanding these weaknesses, Cristianismo points us to another direction in translation history, where translation operates as a method for reporting the past. The representative texts we examine here were authored by Filipinos identified with the nationalist movement of the late nineteenth century, 
who offered an ennobled image of the Philippines to the colonial metropolis (Peralta-Imson, 1997, pp. 9-10). Translation was employed in their writings to historicise indigenous achievements, although with varying outcomes. Cristianismo, for one, was unapologetically assimilationist. Its translational strategy sought to appropriate non-Christian pasts into the grand narrative of universal truth propounded by a colonial religion. The equivalences it was proposing represented Filipinos in a homogenised version of their history, in which Christianity was regarded as the ultimate measure of civilisation (Mojares, 2006, p. 50; Rath, 2016, pp. 229-230).

Contrarily, there were authors whose translations made cultural differences visible. Isabelo de los Reyes was among them. He compiled, transcribed and published folk literatures in a two-volume compendium entitled El folk-lore filipino [Filipino folklore]. For Isabelo, the purpose of folklore was to examine the history of indigenous peoples $(1889, \mathrm{pp} .8,18)$. It was an instrument to reassert their identity and contest dominant ways of knowing. Folklore therefore was as legitimate as science (Anderson, 2005, pp. 12-13). It required academic impartiality, which Isabelo also took as an open invitation for self-criticism:

[T]anta es mi imparcialidad, que he sacrificado á la ciencia el cariño de los ilocanos, pues que se quejan de que he sacado á relucir sus prácticas no muy buenas. (1889, p. 18)

[Such is my impartiality that I have sacrificed the affection of the Ilocanos to science, and so they complain that I have brought their bad practices to light.]

Impartiality, wrote Isabelo, should keep folklorists from including anything imaginary in their work $(1889$, p. $16 ; 1890$, p. 6$)$. This would sound absurd at first glance, considering that Isabelo himself collected tales about mythological creatures and folk heroes. But what he was suggesting was that folklore should not exoticise indigenous peoples through exaggerations about their cultures just to fascinate foreign readers $(1890$, p. 6). Folklore required no appropriation into any universalising system in order to become acceptable.

According to historian Resil Mojares (2006, pp. 352-354), Isabelo's take on folklore was a response to costumbrismo, a literary movement in the nineteenth-century Spanish-speaking world combining romanticist and realist aesthetics to portray local customs. Isabelo, Mojares explains, wanted to "deprimitivize" the Spaniards' portrayals of the Philippines by showing that Filipino traditions were actually analogous to those practised in Europe. He did this by utilising a translation strategy founded on the precept of dynamic equivalence, "procurando conservar su sal y pimienta" (Reyes, 1889, p. 262) [trying to preserve the taste of the text (lit. 'its salt and pepper')]. Unlike Paterno, whose insistence on equivalence pretexted his assimilationist take on history, Isabelo wanted his readers to recognise that equivalence could be achieved without concealing cultural divergences. He similarly underscored the mediated nature of remembrance and how it configured what we now consider historical. As Isabelo explained in his introduction to Biag ni Lam-ang [Life of Lam-ang], an epic poem about the life of one of the most important Filipino folk heroes:

[v]amos á intercalar en los párrafos su traducción literal y por ella notarán los lectores algunas omisiones que atribuyo á infidelidades de la memoria del cantor. (1890, p. 235)

[We are going to insert the literal translation into the paragraphs, for which readers will notice some omissions, which I attribute to the unfaithfulness of the chanter's memory.]

This description may well have been a caveat so that readers could notice the various layers of mediation through which his translation into Spanish was filtered. Biag ni Lam-ang was the first Filipino folk epic ever recorded (Manuel, 
1963, p. 6). Isabelo translated it from Ilocano, a major language spoken in the northern Philippines, with the help of Fr Gerardo Blanco, parish priest of Bangar in the province of La Union.

Isabelo's dynamic view of equivalence compelled him to transform the verses of the Biag ni Lam-ang from sextets, the form in which he obtained the epic from his priestly source, into quatrains. The reason behind this was that Ilocano poetry was typically written in four-line stanzas (1890, p. 236). Isabelo also favoured foreignisation by consciously evoking local colour through realia. Consider this stanza about Lam-ang's origins, which included oblique references to folk customs associated with childbirth:

Ay asaoac a D. Juan/ daytoy man tong̃ó ti agdalagan,/ daytay man sagat quen gasatan,/ dangla quen bayyabas á inuquisán [...] Ay D. Juan esposo mío — esta es la leña que necesita una parida,__el molave y el gasatan,__el danglá y el bayyabas descascarado. (1890, p. 239)

[Ay, Don Juan, my husband!/ This is the wood required by a woman in labour:/ the molave and the gasatan,/ the danglá and the peeled guava.]

Since the names of indigenous plants mentioned in this verse were unexplicitated in the translation, readers may have missed the connotation that the danglá (Vitex negundo) and the bayyabas (Psidium guajava; 'bayabas' in the modernised spelling) were disinfectants, or that the gasatan (Basia s.p.) and the molave (Vitex parviflora) were local hardwood used for making furniture like cribs and beds (Rubino, 2000).

But that was probably the least of Isabelo's concerns. His translation was focussed more on celebrating the specificities of Ilocano history. Rather than concealing the foreignness of these specificities, his translation reminded readers that they were accessing a past that could not be narrated entirely in Spanish. Translation was an arbitrary solution, one whose approach to equivalence was to trust that it could still emerge even if it could not be completely had. This was what made Isabelo stand out as an authentic indigenous voice at a time when scholarly validation was largely determined by one's proximity to European science (Mojares, 2006, p. 349). Isabelo did not always please his contemporaries, but he surely commanded respect. Spanish journalist Joaquín Pellicena y Camacho, writing under the pseudonym Francisco Quintero for the magazine Cultura filipina (1910), described Isabelo's body of work as subjective but conceded that it managed to divulge a wealth of information about the Philippines that would have gone unnoticed overseas (p. 158). Isabelo is still remembered today as the Father of Philippine Folklore.

\section{Translation as history}

It was through translation that two masterpieces of Hispanic Filipino literature became the most recognisable novels in the national canon. The novels Noli me tángere [Touch me not] and El filibusterismo [Subversion] ${ }^{4}$ (Noli and Fili hereafter) by the national hero José Rizal are widely regarded as the foundational texts of the Filipino nation. They were published as Rizal was travelling across Europe after finishing his licentiate in Madrid in 1885. He had gone to Spain three years earlier, stifled by the political climate in the Philippines. The Noli was published in Berlin, Germany in 1887. The Fili came out in Ghent, Belgium in 1891. The novels recount the travails of a SpanishFilipino mestizo named Juan Crisóstomo Ibarra, who became involved in a plot demanding reforms from Spain after a series of events that exposed him to the problems of Filipino society. Assumed dead at the end of the Noli, Ibarra returned with a more revolutionary resolve in the Fili as Simoun, his alter ego. 
The circumstances surrounding the canonisation of Rizal's novels show that translation in Hispanic Filipino literature can also be understood as a mode for commemorating history. Inspired by Walter Benjamin's formulation, we examine translation here as textual afterlives that impinge upon the modes of narrating a national past. Hispanic Filipino literature has generally remained untranslated for Filipino readers, with the Noli and Fili as the most noteworthy exceptions (Lifshey, 2012, p. 13). They were made obligatory readings for students by virtue of Republic Act No. 1425, or the so-called Rizal Law of 1956. The law stipulated that the novels be taught either in their original or unexpurgated editions, or in their English translation. It also instructed the then Board of National Education to cause their translation into English, Tagalog and other major Philippine languages, and to adopt measures to print and distribute copies for free.

The Rizal Law was a rare piece of Philippine legislation foregrounding translation as a matter of national concern. Translations of Rizal's novels certainly existed before 1956, each with its own creative motivations and political agenda (Testa-de Ocampo, 2011, pp. 518-524). Among the early translations of the Noli and Fili were Charles Derbyshire's The social cancer and The reign of greed, respectively, published a little more than a decade into the US occupation. Derbyshire capitalised on a mythologised opposition between a degenerate Spain and a civilising America to preface his translations. He quoted Thomas Carlyle's description of the Battle of Bunker Hill from the Scottish historian's work The French Revolution to accentuate his own portrayal of America as a bulwark of freedom: "Democracy announcing, in rifle-volleys death-winged, under her Star Banner, to the tune of Yankeedoodle-do, that she is born, and, whirlwind-like, will envelop the whole world!" (Derbyshire in Rizal, 1912 [1887], p. 1).

The institutionalisation of literature in public life usually contributes to its standardisation. With the implementation of the Rizal Law, the Philippine government took it upon itself to ensure the circulation of Noli and Fili translations in order "to develop moral character, personal discipline, civic conscience and to teach the duties of citizenship." However, the Rizal Law also paved the way for the creation of different Nolis and Filis. It is difficult to talk about any 'standard' or 'official' translation because there is none. Each school could teach its preferred translation, including those with substantial omissions or alterations (Almario, 2008, p. 2). The process of translating the novels was never sufficiently clarified in these publications. Seldom do we find an outright admission that the translations were based on previous translations into English and hardly ever on the Spanish originals. Even worse, some were passed off as translations even if, strictly speaking, they were adaptations or abridgements at best.

This disregard for translation has had dire consequences. For example, the fourteenth chapter of the Noli introduces one of its most beloved characters, Don Anastasio, nicknamed Tasyo. A well-read eccentric, Tasyo is a fierce critic of colonial Catholicism, speaking at length about its similarities with religions it considered pagan, and pointing out how religious fervour was at odds with rational thought. Many translations into Filipino read in Philippine schools have modified this chapter extensively. Some, like the translation of Guzman, Laksamana and Guzman (1950 [1887]), attenuated Tasyo's objection to the doctrine of Purgatory by oversimplifying the historical arguments propounded by thinkers in the Antiquity and the Middle Ages. Others, like Salazar (1999) and Miranda and Tulaylay (2006), simply omitted this historical discussion altogether. The liberties these authors took were attached to the role of Rizal's novels in the curriculum. Before the recent curricular changes in high schools due to the K-12 program, the Noli and Fili were taught as the main literary components in the subject called 'Filipino' in the third and fourth years. Many translations of the novels that are commercially available to students also 
integrated language instruction in their sequence (Jurilla, 2010, p. 20). Junior and senior students were made to read Rizal's novels in translation to generate a critical reflection on colonial history, as well as to improve their competencies in the national language. This was evident in Miranda and Tulaylay's version. The chapter on Tasyo comprised a pre-reading activity, a discussion guide emphasising the moral of the story, a statement of teaching goals, an abridged translation for the reading proper, an exercise on a specific communication skill (an Oxford-Oregon debate in this case), a post-reading synthesis, and a test on the chapter's major factual points (pp. 100-108).

In effect, generations of Filipino readers have been accessing different retellings of the Noli and Fili, which, it would appear, were not always at par with how it was envisioned in the legislation. Just four years after the Rizal Law was promulgated, its main proponent, the Hispanist Claro Recto, wrote wryly:

¿Cómo permitir que sean leídos en el futuro, no en su original en español sino en espurias traducciones, los escritos de Rizal [...]? (1990 [1960], p. 756)

[How can we allow that Rizal's works be read in the future not in their original version in Spanish but rather in spurious translations?]

It was around this time when the Noli's most successful English-language version was published. It was written by the Filipino diplomat León María Guerrero, who likewise composed a biography of Rizal. Guerrero's translation was widely used in Catholic schools because, Testa-de Ocampo (2011, p. 516) conjectures, he made the Noli more acceptable to church authorities, who had initially opposed the implementation of the law because of Rizal's anticlerical slant. Acceptability, however, does not always guarantee quality: Guerrero's translation has been described by Anderson (1998, pp. 238-247) as a demodernised, bowdlerised, delocalised, de-Europeanised and anachronistic reading of Rizal.

We can focus on one aspect of Guerrero's translation to illustrate this. Guerrero explained in his notes that he rendered the deficient usage of Spanish by some characters in the novel into Filipino English, and the Andalusian accent into an Old South dialect of American English (Rizal, 1969 [1887], p. xvii). These features were used in the following comical scene from the chapter Las dos señoras [The two ladies], in which the iconic Doña Victorina, a rich Filipina who considered herself a Spaniard, got into a public fracas with Doña Consolación, the Filipina wife of a Spanish military officer:

— ¡Mire Ud. con quién se trata! — dice —; ¡no crea Ud. que soy una provinciana o una querida de soldados! En mi casa, en Manila, no entran los alféreces; se esperan en la puerta. // — ¡Hola, Excelentísima Señora Puput! (Rizal, 1982 [1887], p. 266)

Guerrero translated this fragment into English thusly:

'Be careful only with whom you are talking! Maybe you think I am from the province or a hootchie-kootchie of the soldiers! In my house in Manila, if only lieutenant, no entrance, but must waiting by the door!' // 'Excuse me, Your Excellency Madame Sanamabits!' (Rizal, 1969 [1887], p. 300; italics in the translation)

Filipino English was operationalised in Guerrero's translation as a flawed variety of the language. This was certainly not the case in the source text. Except for the words querida [lover] and provinciana [from the province], the sentences Doña Victorina said were normatively neutral. Even the phrase "if only lieutenant, no entrance" in the translation, which suggested that she was constructing her sentences with difficulty, was an overtranslation of an unmarked statement. Then there was puput, a slur uttered by Doña Consolación. It was translated by Guerrero into the phoneticised compound sanamabits [son of a bitch]. 
Examples like these indicate that by using translation as a mode of commemoration, the dissatisfactions of translation are carried into how we imagine history. History, like translation, is skewed, fragmented and imperfect. As Steiner (1975) contends, "[w]e remember culturally, as we do individually, by conventions of emphasis, foreshortening, and omission" (p. 29). These limitations do not undermine the value of translation as history, let alone the pursuit of writing translation histories. After all, every passage of texts from the local to the national, from the Hispanic Filipino to the Filipino, is accomplished inevitably in translation. The Noli and Fili were repatriated into the Filipino canon when they were made available as translations, something which other equally important masterpieces by Filipino authors in Spanish have yet to achieve. It was for this reason that we portray Rizal as a quintessentially Filipino author without much reservation, yet remain unsure if Balmori and Bernabé fit the mould. They are still foreign. They still live in a past enunciated in Spanish. We have not yet reclaimed them in translation.

Approaching translation as history carries with it the responsibility of acknowledging the translatedness of our historical narratives. This, in my opinion, is a significant drawback in how the Noli and Fili are currently taught. Their canonisation as the foremost Filipino novels seems to have de-emphasised their primordial Hispanic roots after they were subsumed under the bigger project of promoting the image of a Filipino nation united under one national language (Garcia, 2017, pp. 28-29). Their identification with the historical narrative of the nation appears to have transposed them from the volatile interstices of translation into the deceptive fixity and uniformity afforded by this national language (cf. Anderson, 2008, pp. 83-84; Castro, 2011, p. 305). For the Noli and Fili to remain truly relevant in Filipino society, they have to be presented conscientiously as translations, which, though bent and swayed by the biases of their agents, adapted and accommodated according to fluctuating contexts of reading, have proven to be strong enough to resist efforts to cohere them into a static retelling of the past. And it is precisely with their omissions, uncomfortable equivalences, and suspiciously uniform accounts of events that these translations serve their purpose of interrogating our vexed historical assumptions as a nation, whose "fiction seeps quietly and continuously into reality" (Anderson, 2006, p. 36).

\section{Conclusion}

Translation (in/of/as) history revisits the conduct of writing translation histories by anatomizing translation as a material, method and mode of commemoration. If indeed history is "a speech-act, a selective use of the past tense" (Steiner, 1975 , p. 29), this model has allowed us to reflect on the creative value of translation in selecting which fragmentary pasts should form the national past. Translation (in/of/as) history is an attempt to understand the problems of writing history as problems of translation. While the examples cited in this article are limited to Hispanic Filipino literature, future research directions should consider how this model can be applied to other contexts of historical writing.

\section{Acknowledgements and dedications}

In memoriam: Santiago Sales Jr. (1955-2018).

\section{References}

Aguilar, F. V., Jr. (2011). Filibustero, Rizal, and the Manilamen of the nineteenth century. Philippine Studies, 59(4), 429-469. 
Almario, V. (2008). Bakit kailangang basáhing muli si Rizal? [Why should Rizal be read anew?]. In Si Rizal: nobelista (pagbása sa Noli at Fili bílang nobela) (pp. 120). Quezon City: The University of the Philippines Press.

Almario, V. (2009). Pagsulyap sa kasaysayan ng pagsasalin [A glimpse into the history of translation]. In G. S. Zafra (Ed.), Salin-suri: panimulang pagmamapa ng mga larangan ng pag-aaral ng pagsasalin sa Filipinas (pp. 19-28). Quezon City: UP Sentro sa Wikang Filipino.

Álvarez Tardío, B. (2012). La miseria y el esplendor del Premio Zóbel [The misery and splendour of the Premio Zóbel]. Perro Berde, 3, 59-65.

Álvarez Tardío, B. (2014). El privilegio de subvertir: la literatura hispanofilipina [The privilege of subverting: Hispanofilipino literature]. Transmodernity, 4(1), 41-53.

Anderson, B. (1998). Spectres of comparison: nationalism, Southeast Asia and the world. London: Verso.

Anderson, B. (2005). Under three flags: anarchism and the colonial imagination. London: Verso.

Anderson, B. (2006). Imagined communities: reflections on the origin and spread of nationalism (Revised ed.). London: Verso.

Anderson, B. (2008). Why counting counts: a study of forms of consciousness and problems of language in Noli me tangere and El filibusterismo. Quezon City: Ateneo de Manila University Press.

Balmori, J. (1928). El libro de mis vidas manileñas [The book of my Manila lives]. Manila: Manila Gráfica.

Bastin, G. (2010). La pertinencia de los estudios históricos sobre traducción en Hispanoamérica [The relevance of historical studies on translation in Hispanic America]. Estudios interdisciplinarios de América Latina y el Caribe, 21(1), 1728.

Bernabé, M. (1929). Cantos del trópico [Songs of the tropic]. Manila: The San Juan Press.

Blancas de San José, F. (1832 [1605]). Memorial de la vida Christiana en lengua tagala (2nd ed.) [Memorial of the Christian life in the Tagalog language]. Manila: Imprenta de José $\mathrm{M}^{\mathrm{a}}$ Dayot.

Brillantes, L. C. (2006). 81 years of Premio Zóbel: a legacy of Philippine literature in Spanish. Makati: Georgina Padilla y Zóbel and the Filipinas Heritage Library.

Burke, P. (2007). Cultures of translation in early modern Europe. In P. Burke \& R.P. Hsia (Eds.), Cultural translation in early modern Europe (pp. 7-38). Cambridge: Cambridge University Press.

Cano, G. (2008). Evidence for the deliberate distortion of the Spanish Philippine colonial historical record in The Philippine Islands 1493-1898. Journal of Southeast Asian Studies, 39(01), 1-30. doi:10.1017/S0022463408000015

Castro, J. E. d. (2011). ¿En qué idioma escribe Ud.?: Spanish, Tagalog, and identity in José Rizal's Noli me tangere. MLN, 126(2), 303-321.

Cheung, M. P. Y. (2012). The mediated nature of knowledge and the pushing-hands approach to research on translation history. Translation Studies, 5(2), 156-171. doi:10.1080/14781700.2012.663599

Craig, A. (1927). Rizal's life and minor writings. Manila: Philippine Education Co., Inc.

D’hulst, L. (2010). Translation history. In Y. Gambier \& L. Van Doorslaer (Eds.), Handbook of translation studies (Vol. 1, pp. 397-405). Amsterdam: John Benjamins.

Delisle, J. (2008). Historiographie, notions, sens, citations, CD-ROM. Mutatis Mutandis, 1(1), 81-96.

Donoso Jiménez, I. (2014). Ensayo historiográfico de las letras en Filipinas [Historiographical essay on Philippine letters]. Transmodernity, 4(1), 7-23.

Fernández Vítores, D. (2017). El español: una lengua viva. Informe 2017 [Spanish: a living language. 2017 report]. Madrid: Instituto Cervantes.

Foz, C. (2006). Translation, history and the translation scholar. In G. Bastin \& P. F. Bandia (Eds.), Charting the future of translation history (pp. 131-144). Ottawa: University of Ottawa Press.

Fradera, J. M. (2001). La formación de una colonia. Objetivos metropolitanos y transacciones locales [Forming a colony: metropolitan objectives and local transactions]. In M.D. Elizalde, J.M. Fradera, \& L. Alonso (Eds.), Imperios y naciones en el Pacífico-la formación de una colonia: Filipinas (Vol. I, pp. 83103). Madrid: CSIC. 
Gallo, A. (2012). Voces hispanas de la Filipinas de hoy [Hispanic voices in the Philippines today]. Perro Berde, 3, 51-57.

Garcia, J. N. C. (2017). Translation and the limits of minority discourse in the Philippines. Continuum, 31(1), 24-32. doi:10.1080/10304312.2016.1262093

Guillermo, R. (2009). Translation and revolution: a study of Jose Rizal's Guillermo Tell. Quezon City: Ateneo de Manila University Press.

Hau, C. S., \& Tinio, V. L. (2003). Language policy and ethnic relations in the Philippines. In M. E. Brown \& S. Ganguly (Eds.), Fighting words: language policy and ethnic relations in Asia (pp. 319-341). Cambridge, MA: The MIT Press.

Jurilla, P. M. B. (2010). Bibliography of Filipino novels, 1901-2000. Quezon City: University of the Philippines Press.

Lifshey, A. (2012). The Magellan fallacy: globalization and the emergence of Asian and African literature in Spanish. Ann Arbor: University of Michigan Press.

Lifshey, A. (2016). Subversions of the American century: Filipino literature in Spanish and the transpacific transformation of the United States. Ann Arbor: University of Michigan Press.

Mabini, A. (1935). The Philippine Revolution. Manila: National Library of the Philippines.

Manuel, E. A. (1963). A survey of Philippine folk epics. Asian Folklore Studies, 22, 1 76. doi:10.2307/1177562

Medina, J. T. (1896). La imprenta en Manila desde sus orígenes hasta 1810 [The printing press in Manila from its origins to 1810]. Santiago de Chile: The author.

Miranda, L. L., \& Tulaylay, M. D. L. (2006). Obra maestra: Noli me tangere. Manila: Rex Bookstore.

Mojares, R. B. (2006). Brains of the nation: Pedro Paterno, T. H. Pardo de Tavera, Isabelo de los Reyes and the production of modern knowledge. Quezon City: Ateneo de Manila University Press.

Morga, A. d., \& Rizal, J. (1890 [1609]). Sucesos de las islas filipinas [Events from the Philippine Islands]. Paris: Librería de Garnier Hermanos.

Morga, A. d., \& Retana, W. (1909 [1609]). Sucesos de las islas filipinas (New ed.). Madrid: Librería General de Victoriano Suárez.

Ofilada Mina, M. (2014). La singularidad de la literatura filhispana [The singularity of Fil-hispanic literature]. Transmodernity, 4(1), 54-66.

Paloposki, O. (2013). Translation history: audiences, collaboration and interdisciplinarity. MonTI. Monografías de Traducción e Interpretación, 5, 213-239.

Pardo de Tavera, T. H. (1903). Biblioteca Filipina, ó sea, catálogo razonado de todos los impresos, tanto insulares como extranjeros, relativos á la historia, la etnografía, la lingüística, la botánica, la fauna, la flora, la geología, la hidrografía, la geografía, la legislación, etc., de las Islas Filipinas, de Joló y Marianas [The Filipino library, or a detailed catalogue of all printed materials, both insular and foreign, related to the history, ethnography, linguistics, botany, fauna, flora, geology, hydrography, geography, legislation, etc., from the Philippine Islands, Jolo and the Marianas]. Washington: The Library of Congress and The Bureau of Insular Affairs, War Department.

Paterno, P. A. (1892). El cristianismo en la antigua civilización tagálog [Christianity in the ancient Tagalog civilisation]. Madrid: Imprenta Moderna.

Peña, W. d. 1. (2001). The Spanish-English language war. Linguae et Litterae, IV-V, 628.

Peralta-Imson, M. E. (1997). Philippine literature: Spanish evolving a national literature. Linguae et Litterae, II, 1-19.

Pinpin, T. (2011 [1610]). Librong pagaaralan nang manga Tagalog nang uicang Castila [Book with which the Tagalogs should study the Castilian language]. (D. L. Woods, Ed.). Manila: UST Publishing House.

Quilis Sanz, M. J., Quilis, A., \& Casado Fresnillo, C. (1997). Los filipinismos y otras palabras de Filipinas contenidas en el «Diccionario» de la Academia [Filipinisms and other words from the Philippines contained in the dictionary of the Royal Academy of the Spanish Language]. Boletín de la Real Academia Española, LXXVII(CCLXX), 7-55.

Quintero, F. (1910, May). Apuntes bibliográficos [Bibliographical notes]. Cultura filipina, 1(2), 153-176.

Rafael, V. L. (2005). The promise of the foreign: nationalism and the technics of translation in the Spanish Philippines. Durham: Duke University Press. 
Rath, I. (2016). Pedro Alejandro Paterno's La antigua civilización tagálog (1887): an attempt to (re)construct one's own religious past. In M. Arnez \& J. Sarnowsky (Eds.), The role of religions in the European perception of insular and mainland Southeast Asia (pp. 227-238). Newcastle upon Tyne: Cambridge Scholars Publishing.

Recto, C. M. (1990 [1960]). Por los fueros de una herencia [For the right to an inheritance]. In I. Medina \& M. Feliciano (Eds.), The complete works of Claro M. Recto (Vol. 9, pp. 751-760). Pasay: Claro M. Recto Memorial Foundation.

Reyes, I. d. 1. (1889). El folk-lore filipino (Vol. 1) [Filipino folklore]. Escolta: TipoLitografía de Chofré y C. ${ }^{\text {a }}$.

Reyes, I. d. 1. (1890). El folk-lore filipino (Vol. 2). Manila: Imprenta de Santa Cruz.

Rizal, J. (1912 [1887]). The social cancer (C. Derbyshire, Trans.). Manila: Philippine Education Company.

Rizal, J. (1950 [1887]). Noli me tangere (D. d. Guzman, F. Laksamana, \& M. O. d. Guzman, Trans., 5th ed.). Manila: National Book Store.

Rizal, J. (1969 [1887]). Noli me tangere (L. M. Guerrero, Trans.). Hong Kong: Longman.

Rizal, J. (1982 [1887]). Noli me tangere (M. Russotto, Ed., 2nd ed.). Caracas: Biblioteca Ayacucho.

Robbins, B. (2018). What world history does world literature need? In M. Hawas (Ed.), The Routledge companion to world literature and world history (pp. 194-206). London: Routledge.

Rubino, C. (2000). Ilocano dictionary and grammar: Ilocano-English, English-Ilocano. Honolulu: University of Hawai'i Press.

Rundle, C., \& Rafael, V. L. (2016). History and translation: the event of language. In Y. Gambier \& L. Van Doorslaer (Eds.), Border crossings: translation studies and other disciplines (pp. 23-47). Amsterdam: John Benjamins.

Salazar, A. E. (1999). Noli me tangere. Quezon City: JMC Press.

Scott, W. H. (1984). Prehispanic source materials for the study of Philippine history (Revised ed.). Quezon City: New Day Publishers.

Steiner, G. (1975). After Babel: aspects of language and translation. New York: Oxford University Press.

Testa-de Ocampo, A. M. (2011). The afterlives of the 'Noli me tangere'. Philippine Studies, 59(4), 495-527.

Veyra, J. C. d. (1961). La hispanidad en Filipinas [Hispanicity in the Philippines]. Madrid: Publicaciones del Círculo Filipino.

Vidal Claramonte, M. C. Á. (2018). La traducción y la(s) historia(s): nuevas vías para la investigación [Translation and history/ies: new avenues for research]. Granada: Editorial Comares.

Zialcita, F. (2009). Preguntas acerca de la identidad filipina [Questions about the Filipino identity]. In M. D. Elizalde Pérez-Grueso (Ed.), Repensar Filipinas: política, identidad y religión en la construccón de la nación filipina (pp. 159-179). Barcelona: CSIC-Casa Asia.

\section{Notes}

${ }^{1}$ Tagalog is the basis of the Philippine national language called Filipino. The term Pilipino to refer to language was used only in 1959 as a substitute to Wikang Pambansa [National Language], which had been coined in 1939 to describe Tagalog. The change from Pilipino to Filipino happened in 1973. Filipino was adopted later on in the 1987 Constitution as the name of the national language. This was the same constitution that abrogated the mandatory teaching of Spanish in Philippine schools. Note further that English is a co-official language in the Philippines.

${ }^{2}$ Unless otherwise specified, all translations are mine. For bilingual passages, the translation is derived from Spanish. Departures from modern spelling and accentuation norms follow the language conventions of the period.

${ }^{3}$ The Philippines was governed by the Spanish Crown through the Viceroyalty of New Spain, located in Mexico.

${ }^{4}$ For a detailed discussion of the meaning of the Spanish word filibusterismo, specifically its etymological connection to piracy, please see Aguilar (2011, pp. 435-437). 